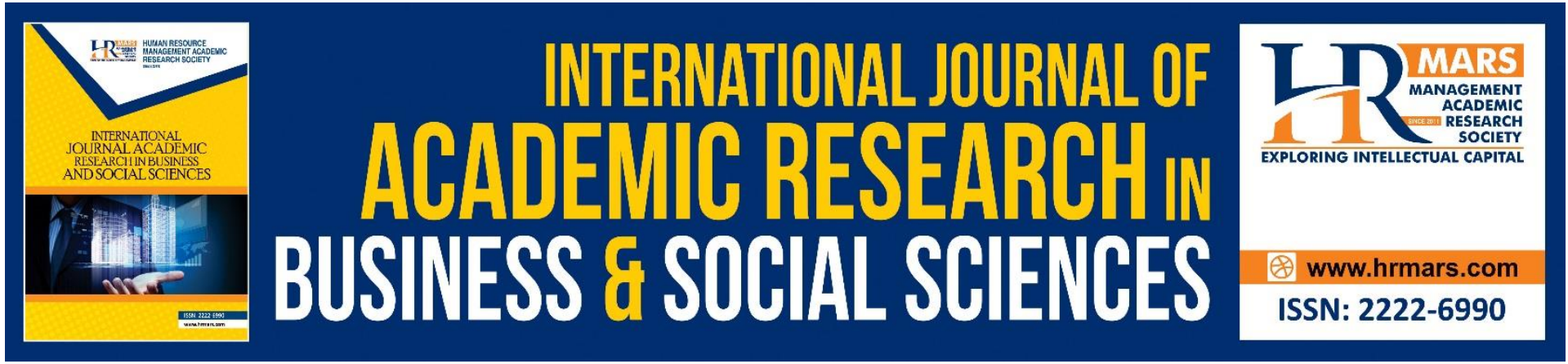

\title{
ICT and Economic Integration on Growth in ASEAN Region: Dynamic Panel GMM Approach
}

Muhammad Bilal Ahsin, Jerome Kueh, Muhammad Asraf bin Abdullah

To Link this Article: http://dx.doi.org/10.6007/IJARBSS/v11-i8/10795

DOI:10.6007/IJARBSS/v11-i8/10795

Received: 12 June 2021, Revised: 14 July 2021, Accepted: 02 August 2021

Published Online: 16 August 2021

In-Text Citation: (Ahsin et al., 2021)

To Cite this Article: Ahsin, M. B., Kueh, J., \& Abdullah, M. A. bin. (2021). ICT and Economic Integration on Growth in ASEAN Region: Dynamic Panel GMM Approach. International Journal of Academic Research in Business and Social Sciences, 11(8), 1060-1075.

Copyright: (c) 2021 The Author(s)

Published by Human Resource Management Academic Research Society (www.hrmars.com)

This article is published under the Creative Commons Attribution (CC BY 4.0) license. Anyone may reproduce, distribute, translate and create derivative works of this article (for both commercial and non-commercial purposes), subject to full attribution to the original publication and authors. The full terms of this license may be seen at: http://creativecommons.org/licences/by/4.0/legalcode

Vol. 11, No. 8, 2021, Pg. 1060 - 1075

http://hrmars.com/index.php/pages/detail/IJARBSS

JOURNAL HOMEPAGE

Full Terms \& Conditions of access and use can be found at http://hrmars.com/index.php/pages/detail/publication-ethics 


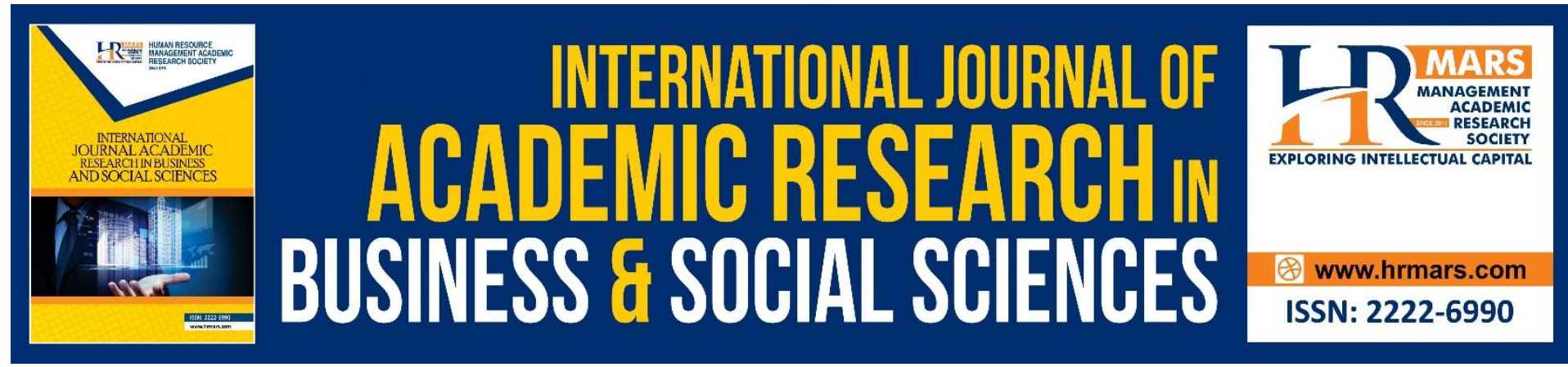

\title{
ICT and Economic Integration on Growth in ASEAN Region: Dynamic Panel GMM Approach
}

\section{Muhammad Bilal Ahsin, Jerome Kueh, Muhammad Asraf bin Abdullah}

Faculty of Economic and Business, Universiti Malaysia Sarawak, 94300 Kota Samarahan, Sarawak, Malaysia

\begin{abstract}
Southeast Asian Nations (ASEAN) observed rapid economic growth in the last few decades. This study aims to investigate whether economic integration and information and communication technology (ICT) promotes economic growth in ASEAN. It further examines the role of ICT for economic integration and growth relationship with respect to ICT readiness and usage. The study undertook panel data over 21 years (1997 - 2017) and employed Generalized Method of Moments approach for estimation of results. The results revealed that economic integration and ICT enhance economic growth. Moreover, enhanced ICT stimulates the impact of economic integration on economic growth. The results also confirmed a more substantial effect of ICT readiness on economic growth as compared to ICT usage.
\end{abstract}

Keywords: Economic Integration, Information And Communication Technology, Economic Growth, ASEAN, GMM

\section{Introduction}

Economic growth enhancement is the principal objective for every economy that has been significantly contributed by international trade (Shuaibu, 2015 and Ogbuabor et al., 2019). Krugman (1979) suggested that international trade of differentiated products can be beneficial as market forces will channel resources to more productive sectors, causing efficiency enhancement. The increase in efficiency will further enhance total productivity and growth in the economy. To elevate economic growth, every country aims to enhance international trade, but there are specific trade barriers. Therefore, many countries unified their economic policies to eliminate trade barriers fully or partially. This consolidation and minimization of tariff and non-tariff restrictions on trade is known as economic integration (Mohanty \& Pohit, 2007; Danquah et al., 2013; Heshmati, 2016; Ogbuabor et al., 2019).

Association of Southeast Asian Nations (ASEAN) is economic integration of ten Asian countries. It was established on $8^{\text {th }}$ August, 1967 with the purpose of enhancing economic growth, cultural development and social progress to make it peaceful and prosperous through integration. ASEAN observed a significant rise in trading activities in the last few decades due to regional as regional trade cooperation was an imperative aspect of ASEAN's declared common goals (Hew, 2008). ASEAN Free Trade Area (AFTA) agreement contributed 
immensely towards regional trade expansion. ASEAN officially introduced AFTA in 1992 to gain regional strength through production. AFTA organized multinational cooperative arrangements to reduce intra-ASEAN tariff.

Moreover, ASEAN declared a separate negotiation of free trade in the shape of a Regional Comprehensive Economic Partnership with its six main trading partners Australia, China, India, Japan, New Zealand, and South Korea. To further expand regional cooperation and growth ASEAN also established the ASEAN Economic Community (AEC) in 2015. The main target of $A E C$ was to eliminate intra-regional tariffs and formal restrictions on services sector. Additionally, it simplified the cross-border processes to reduce trade costs (ASEAN Secretariat, 2017). Despite all the efforts on economic integration, ASEAN is still at an early stage of integration. The main focus is on trade activities because different countries are at varying levels of integration.

The recent progress in productivity and growth for developed countries like Singapore, South Korea and Japan is associated with enhancement in Information and Communication Technology (ICT) sector. In this perspective, developing ASEAN countries also started to focus on ICT for export escalation. Considering the export-led strategies of ASEAN economies the role of ICT is quite inevitable. On the other hand, recent internet and digital adoption is the most ground-breaking factor that helped enhance economic integration in the last few years. In 2015, ASEAN e-commerce was worth 5.5 billion USD that became almost 11 billion USD in 2017 but this figure became double in one year. In 2018, ASEAN e-commerce reached 23 billion USD, that showed $62 \%$ compound annual growth in the last three years (Autrade, 2018).

Internet is considered as the most revolutionary element in ICT development. World Wide Web was available in 1989 whereas the fixed internet was available in the ASEAN since 1992, which was not so late but ASEAN started ICT cooperation in 2005. Since its formation, ICT development has evolved ASEAN at a phenomenal pace as 78\% of ASEAN citizens are getting benefits from the application and advancement of ICT in various fields (ASEAN ICT Masterplan, 2015). In 2010, ASEAN prepared ASEAN ICT Masterplan 2015 to achieve exponential growth with the perspective of ICT adoption to spur economic transformation in region. In this regard, infrastructure and human capital development were considered as key factors. Overall, the plan had four primary outcomes to make ICT an engine for economic growth, ASEAN's recognition as global ICT hub, enhance life quality of ASEAN citizens, and contribute towards ASEAN integration. The first pillar of ASEAN ICT Masterplan 2015 was based on economic transformation through trade and investment promotion involving ICT. After the foundation of AEC, ICT also gained importance in developing human resource skills, industrial sector innovation and the invention of knowledge. After ICT Masterplan 2015 ASEAN also launched ICT Masterplan 2020 to utilize the ICT in ASEAN single market. The digital adoption of ASEAN member countries in various dimensions reported that ICT adoption increased in 2016 compared to 2014 (World Development Indicator, 2019).

The average annual GDP Per Capita growth rate of ASEAN from 1998 to 2007 was 4.10 percent but the average came down to 3.70 percent in last decade (WDI, 2019). ASEAN is striving to promote economic integration and growth in the region but the member countries have observed significant heterogeneity concerning economic integration (Preepremmote, 
Santipolvut \& Puttitanun, 2018). Further, different ASEAN regions have different ICT adoption levels known as digital divide (ASEAN ICT Master Plan, 2015). So, the declined economic growth and heterogeneity in economic ntegration and ICT adoption set the basis for this investigation. Therefore, this study aims to investigate the impact of economic integration and ICT on economic growth. The study will also explore the role of ICT for economic integration and growth nexus. This is imperative for policymakers and government authorities for economic growth enhancement through economic integration and ICT. It will also highlight the role of ICT that can bridge the digital divide in ASEAN region.

\section{Review of Literature}

Many past studies suggested that economic integration enhances economic growth. (Balassa, 1961; Haveman, Lei, \& Netz, 1998). Balassa (1961) further computed integration by applying the sectoral approach to examine the impact of international trade on growth. Balassa (1961) observed the dynamic implications of economic integration on economic growth employing technological progress, competition and economies of scale. Haveman etal (1998) conducted a panel data study to observe the impact of various international integration types on economic growth for the period 1970 to 1989. They confirmed positive effect of trade intensity on economic growth.

ASEAN region and economies observed a significant rise in economic integration due to trade liberalization for the last few decades. Though, many empirical studies confirmed the longrun relationship between exports and Gross Domestic Product (GDP) (Ahmad \& Harnhirun, 1996; Hsiao \& Hsiao, 2006; Ridzuan et al., 2016; Tan \& Tang, 2016). The export-led growth hypothesis provides more clear support considering specific time and country. However, other instances revealed a more composite structure for GDP and export relationship by confirming a bi-directional causal relationship between exports and GDP. Moreover, studies based on trade and -term growth relationships revealed mixed results (Bhatt, 2014; Tan \& Tang, 2016).

Sharma and Chua (2000) conducted a study on selected ASEAN countries using the gravity model to investigate the impact of intra-regional trade of Malaysia, Indonesia, Singapore, Philippines and Thailand. The researchers observed an association between the trade of ASEAN countries and economy size. Similarly, Kien (2009) also conducted a panel data study using the gravity model to examine the effects of AFTA in ASEAN. The author observed that export flow increased in proportion to GDP and the creation of AFTA enhanced significant trade among members. Vogiatzoglou and Nguyen (2016) also studied economic openness on short and long-run economic growth. The authors considered three measures for economic integration, including export, import, and FDI over time from 1980 to 2014 for five ASEAN member countries. The results were estimated by using vector error correction cointegration. The findings indicated long-run equilibrium between GDP and economic openness for all ASEAN-5 countries.

Additionally, the authors also concluded that imports, exports and FDI have a positive and significant impact on long and short-run economic growth for ASEAN-5. Bong and Premaratne (2018) also conducted a panel data analysis on ASEAN region to investigate the effects of economic integration on growth by using Generalized Method of Moments (GMM). The authors took data of 43 years from 1970 to 2013 and reported a significant positive impact of 
regional economic integration on economic growth. Moreover, they concluded that political stability and elimination of corruption play a vital role in enhancing economic growth and enhancing economic growth and enhancing economic growth and increased regional economic integration of ASEAN.

On the other hand, Oncel and Lubis (2017) suggested that only FDI impacts positively on per capita output of ASEAN 5, including Malaysia, Indonesia, Philippines, Thailand and Singapore. They also reported that free trade dummy variable and trade were insignificant to output per capita before implementing zero-tariff policy. Hussin and Saidin (2012) also investigated the impact of Openness, FDI and gross fixed capital formation on economic growth for the period of 1981 to 2008. The researchers used Pooled OLS, fixed effect and random effect models to estimate the results and concluded openness is not associated with economic growth for Thailand, Malaysia, and the Philippines. Considering empirical studies concerning ICT in the ASEAN region, Ahmed and Ridzuan (2013) conducted a panel data study over the period of 1975 to 2006 for ASEAN 5 and ASEAN 3. The study found that investment in telecommunication had a significant and positive impact on economic growth in both regions. Similarly, Sassi and Goaied (2013) argued that a fixed telephone line, internet and mobile phone subscription significantly impacts economic growth for the Middle East and North African (MENA) countries.

A comparative study was conducted by Dimelis and Papaioannou (2010) to investigate the impact of ICT usage in the production sector. The study undertook two time periods from 1980 to 1990 and 1990 to 2000 and reported that ICT had a strong impact on the EU and USA's economic growth in the 1990s but remain consistent in the EU thereafter. Vu (2011) empirically examined the effect of mobile phone, PC and internet users on economic growth and confirmed that all these factors have a significant and positive impact on economic growth. Moreover, the researcher argued that ICT's role is relatively stronger from 1996 to 2005 compared to 1976- 1985 and 1986-1995. Similarly, Ward and Zheng (2016) confirmed the positive impact of fixed telephones and mobile phones on different provinces of China. However, the authors observed a diminishing impact of the fixed telephone line on economic growth after 2001 due to the development and conversion of line telephone users into mobile phone users. Jorgenson and $\mathrm{Vu}$ (2016) examined the impact of ICT on the world's 14 largest economies and revealed that ICT had a significant and positive impact on economic growth.

There are few empirical studies that investigated the impact of ICT on economic growth and reported mixed results and heterogeneous outcomes based on development levels. The empirical study conducted by Yousefi's (2011) on 62 countries for the time period 2000-2006 argued that the impact of ICT varies among different income groups. The author reported that although ICT plays a significant role for upper middle and higher income countries but unable to increase economic growth for lower-middle income countries. Zuhdi et al. (2012) employed input-output approach through decomposition analysis based on various industrial sectors for Indonesia (developing country) and Japan (developed country). The datasets used for Japan were from 2000 to 2005 and from 1995 to 2005. Similarly, datasets used for Indonesia were from 1990 to 2005 and from 1990 to 1995. The results revealed that impact of ICT had significant impact on economy of Japan but insignificant impact on economy of Indonesia. 
Moreover, few studies investigated complementary factors and channels for ICT to promote economic growth. The study of Kumar (2012) employed autoregressive distributed lagged model over a period 1970-2010 for Sub Saharan Africa region. Kumar confirmed that the impact of financial development and ICT when coupled become significant and positive on short-run and long-run income. In the same way, Sassi and Goaied (2013) investigated the impact of financial development on economic growth with and without ICT. They revealed that although financial development had a negative impact on economic growth. However, this negative effect of financial development was resolved by internet and mobile phone usage.

ASEAN Secretariat (2014) examined the economic integration-growth relationship and reported country-level heterogeneity in the ASEAN region. Many theoretical and empirical studies on economic integration and growth nexus revealed mixed results (Harrison, 1996; Yanikkaya, 2003; Dowrick \& Golley, 2004 and Rassekh, 2007). Furthermore, ICT has been a significant contributor to economic growth (Dewan, 2000; Cardona, Kretschmer, \& Strobel, 2013 and Ishida, 2015). Although ICT adoption increased for ASEAN region (World Development Indicator, 2019), various countries in the ASEAN region are at different developmental levels of ICT known as digital divide (ASEAN ICT Master Plan, 2015). This digital divide can carb economic growth. Further, there is also a literature gap aimed at the role of ICT for economic integration and growth relationship considering country-level heterogeneity for ICT and economic integration.

\section{Data and Research Model}

The study is based on a panel dataset for all ten ASEAN countries from 1997 to 2017. Annual data is obtained from various data sources, including World Bank, International Telecommunications Union (ITU) and Penn World Table (PWT) version 9.1. The observations are constructed as a non-overlapping average of three years that provides seven periods for ten ASEAN countries. The -year average is constructed to mitigate business cycle fluctuations and capture the real effect of economic integration on growth in long- and medium-term variations instead of short-term variations. More particularly, non-overlapping average assists in drawing results to be less subjective to the permanent and temporary shocks. Ehigiamusoe and Lean (2019) also suggested that many previous studies on economic integration used non-overlapping average data.

New Trade Theory and Endogenous Growth Model serve as theoretical support for this study. New Trade Theory states that increase in trade or enhanced economic integration upsurge economic growth. Moreover, Endogenous Growth Model postulates that determinants of economic growth are explained inside the model. AK model is a form of endogenous growth model that is based on physical capital accumulation. The model uses a basic production function

$Y=A K$

Where, $Y$ shows the level of production, $A$ denotes technology and $K$ shows capital accumulation. This study extends above mentioned AK model by adding economic integration as duly supported by New Trade Theory. The study also examines the impact of ICT on economic growth. Further, the study also adopts human capital and employment rate as 
control variables (Paparas, Richter, \& Paparas, 2015; Ahmed \& Ahmad, 2016 and Murphy, \& O'Reilly, 2019). Generalized Method of Moments (GMM) model (Hansen, 1982) will estimate the results. GMM considers the instrumental variable approach to estimate the results. Since the best fit instrumental variable is usually unknown so, the lagged dependent variable is used as instrumental variable to infer results. These instrumental variables of the dynamic GMM estimators follow moment conditions and are used for short panels where the cross sections are greater than the time intervals (Arellano \& Bond, 1991; Arellano \& Bover, 1995; Blundell \& Bond, 1998). GMM is also used to rule out the problems of serial correlation and endogeneity. Further, to check the veracity of the results the post-analysis tests of Sargran and Arellano Bond are used to check the validity of the instruments and serial correlation respectively.

In this paper, GMM is used to capture the dynamic impact of economic growth, to control the impact of possible omitted variables and to counter possible endogeneity in the model. In this regard, Equation (1) can be rewritten as:

$$
\begin{aligned}
\ln E G_{i t}=\beta_{0}+ & \beta_{1} \ln E G_{i t-1}+\beta_{2} \ln E I_{i t}+\beta_{3} \ln I C T_{i t}+\beta_{4} \ln H C_{i t}+\beta_{5} \ln E M P_{i t} \\
& +\varepsilon_{i t}
\end{aligned}
$$

Where, $t$ shows period for each $i$ country. Further, in Equation $2 E G, E I, I C T, H C, E M P$ and $\varepsilon$ denotes Economic Growth, Economic, ICT, Human Capital, Employment Rate and disturbance term respectively. Betas denote coefficients and $I n$ natural indicates logarithm in equation for all variables to standardize the dataset. The scope of the study is not limited to impact of economic integration and ICT on economic growth but it will also explore the role of ICT for economic integration and growth relationship. So, Equation (2) can be rewritten as

$$
\begin{aligned}
\ln E G_{i t}=\beta_{0}+ & \beta_{1} \ln E G_{i t-1}+\beta_{2} \ln E I_{i t}+\beta_{3} \ln I C T_{i t} * \ln E I_{i t}+\beta_{4} \ln H C_{i t}+\beta_{5} \ln E M P_{i t} \\
& +\varepsilon_{i t}
\end{aligned}
$$

The study considers ICT concerning readiness and usage. Therefore, regression analysis will be based on four models as the models presented in Equation 2 and Equation 3 will be examined with respect to ICT readiness and usage.

This section includes the definitions and discussion regarding measurement for all variables involved in the study.

\section{Economic Growth}

Economic growth is referred as the economic expansion of a country that can be usually estimated through various approaches but GDP is the most common measure for economic growth. Hussin and Saidin (2012) mentioned that the economic growth is the measure of aggregate proliferation in the economic sectors of a country hence; the GDP best defines. Similarly, Masoud (2014) defined economic growth as increase in per capita gross domestic product (GDP). Sukirno (2012) defined economic growth as development of activities in the country that enhances the production of goods and services. Conclusively, economic growth can be defined as the change in the level of goods and services produced by a country over a specific period of time (Kamarudin, Wahab, Mohamad, \& Saudi, 2018). This study incorporates economic growth as the dependent variable and the proxy selected for economic growth is real GDP growth. This proxy for economic growth is selected based on developmental economics literature as many researchers claimed that GDP growth is a better 
measure to explain economic growth (Makki \& Somwaru, 2004; lyidoğan et al., 2017; Bong \& Premaratne, 2018 and Latif et al., 2018).

\section{Economic Integration}

Viner (1950) entrenched the framework of economic Integration by defining trade creation and trade diversion. There are different definitions for economic integration presented by various researchers. Balassa (1961) defined economic integration precisely as the abolition of discrimination within an area. Kahnert et al. (1969) explained the process of economic integration as progressive elimination of discriminations that occur at domestic borders. Moreover, Lipsey (1960, P 496) defined economic integration as a branch of tariff theory that deals with the effects of geographical discriminatory changes in trade barriers. Machlup (1977) defined economic integration as the process through which different economies form a larger economic region. Economic integration is the explanatory variable of the study. Many previous empirical studies suggested mainly two economic integration measures: trade openness and various indexes of globalization. Although, various studies selected trade openness as a proxy for economic integration (Grubert \& Mutti, 2000; Devereux, Griffith \& Klemm, 2002; Loretz, 2007 and Bong \& Premaratne, 2018) but a better premise is to adopt an index. It is also widely accepted that premise of economic integration is a multi-faceted concept. So, this study adopts Konjunktur Forschungsstelle (KOF) index of globalization as a proxy for economic integration (Steiner \& Martin, 2012; Khalid \& Marasco, 2019 and Nguyen, Bui \& Vo, 2019).The increase in KOF Index reflects higher side of economic integration. The KOF index of globalization is based on economic, social and political (Dreher, 2006).

\section{Information and Communications Technology (ICT)}

The term IICT primarily appeared in mid-1980s. Yusuf (2005) described ICT as the diversified application of computing, telecommunication, communication and satellite technology. Similarly, Parvez (2011) defined ICT as all sorts of electronic systems used to broadcast telecommunications and mediate communications. ICT is the amalgamation of computer and communication technology where computer technology devices help store and process information in the digital form. Riyasat and Fatima (2008) defined ICT as Integrating computing, networking and information processing technologies and their applications. ICT is selected as an explanatory variable and moderator in this study. Many past studies used different proxies to measure ICT i.e. landline telephone connections, Mobile Phone Customers and Internet users. In literature, ICT was measured in three ways, including readiness, use and impact of ICT. The readiness of ICT dwells on level of ICT infrastructure and access, whereas ICT use focuses to measure the intensity of ICT usage. Due to data limitations, this study adopts two proxies to measure ICT by considering its usage and readiness that will also assist in checking robustness. To measure ICT with usage perspective, Internet users per hundred populations are selected as a proxy (Roller \& Waverman, 2001 and Raheem, Tiwari, \& Balsalobre-lorente, 2019). Whereas, Mobile Phone Subscription is considered to measure ICT readiness (Kumar \& Kumar, 2019 and Maiti \& Awasthi, 2019).

\section{Human Capital}

Human capital is another significant determinant of economic growth (Barro, 1991). Human Capital is considered as control variable for the study. The proxy selected for human capital is PWT human capital index based on years of schooling and returns to education (Ahmed \& 
Ahmad, 2016 and Murphy, \& O'Reilly, 2019). The increase in the index shows higher human capital for the respective country.

\section{Employment Rate}

Employment growth is also an essential driver of economic growth (Paparas, Richter, \& Paparas, 2015). It is also considered a control variable in our growth function. The proxy selected for Employment Growth is total employment per million and data is taken from PWT (Baksa \& Kónya, 2019).

\section{Results and Discussion}

The results and discussion section includes descriptive and regression analysis outcomes along with diagnostic tests for regression analysis.

Table 1: Descriptive Statistics

\begin{tabular}{llllll} 
Variable & Obs & Mean & Std. Dev. & Min & Max \\
\hline InEG & 70 & 10.8511 & 0.6982 & 9.5040 & 12.0165 \\
InEI & 70 & 1.7494 & 0.1237 & 1.4610 & 1.9301 \\
InEI * InIU & 70 & 1.3826 & 2.0698 & -5.8577 & 3.6821 \\
InEI * InMS & 70 & 11.7726 & 2.5295 & 5.8094 & 15.4866 \\
InIU & 70 & 0.7225 & 1.2335 & -4.0092 & 1.9312 \\
InMS & 70 & 6.6785 & 1.14931 & 3.8929 & 8.5960 \\
InHC & 70 & 0.3545 & 0.09528 & .17145 & 0.5813 \\
InEP & 70 & 1.0189 & 0.7839 & -.86012 & 2.0793 \\
\hline
\end{tabular}

Table 1 depicts descriptive statistics of the variables including total number of observations Mean, Standard deviation and Minimum and Maximum values. The total numbers of observations are 70 for each variable. The value of economic Growth ranges between 9.54 to 12.01 with mean of 10.85 and standard deviation of 6982652 indicating different economic growth in different countries (Putranti, 2016). Similarly, descriptive statistics also shows heterogeneity across countries for economic integration (Preepremmote, Santipolvut \& Puttitanun, 2018), having a mean of 1.7494 and standard deviation of 0.1237 . Internet Users and Mobile Phone Subscribers, the proxies for ICT also have higher heterogeneity with higher standard deviation values of 1.2335 and 1.1493 , respectively. 
Table 2: System GMM Regression Analysis

\begin{tabular}{|c|c|c|c|c|}
\hline & $\begin{array}{l}(1) \\
\ln E G\end{array}$ & $\begin{array}{l}(2) \\
\ln E G\end{array}$ & $\begin{array}{l}\text { (3) } \\
\text { InEG }\end{array}$ & $\begin{array}{l}(4) \\
\ln E G\end{array}$ \\
\hline Constant & $\begin{array}{l}-0.363 \\
(-0.21)\end{array}$ & $\begin{array}{l}-0.747 \\
(-0.45)\end{array}$ & $\begin{array}{l}-0.518 \\
(-0.30)\end{array}$ & $\begin{array}{l}-0.505 \\
(-0.32)\end{array}$ \\
\hline InEG_L1 & $\begin{array}{l}0.800^{* * * *} \\
(3.68)\end{array}$ & $\begin{array}{l}0.918^{* * * *} \\
(3.98)\end{array}$ & $\begin{array}{l}0.821^{* * * *} \\
(3.74)\end{array}$ & $\begin{array}{l}0.951^{* * * *} \\
(4.07)\end{array}$ \\
\hline InEI & $\begin{array}{l}1.898^{* * * *} \\
(9.40)\end{array}$ & $\begin{array}{l}1.186^{* * * *} \\
(3.88)\end{array}$ & $\begin{array}{l}1.917^{* * * *} \\
(9.21)\end{array}$ & $\begin{array}{l}0.863^{* *} \\
(2.07)\end{array}$ \\
\hline $\mathrm{InHC}$ & $\begin{array}{l}-2.442^{*} \\
(-1.72)\end{array}$ & $\begin{array}{l}-2.197^{*} \\
(-1.67)\end{array}$ & $\begin{array}{l}-2.718^{*} \\
(-1.85)\end{array}$ & $\begin{array}{l}-2.408^{*} \\
(-1.79)\end{array}$ \\
\hline InEP & $\begin{array}{l}0.110 \\
(0.82)\end{array}$ & $\begin{array}{l}0.0193 \\
(0.14)\end{array}$ & $\begin{array}{l}0.0917 \\
(0.68)\end{array}$ & $\begin{array}{l}0.0102 \\
(0.07)\end{array}$ \\
\hline $\ln I U$ & $\begin{array}{l}0.0463^{* *} \\
(2.15)\end{array}$ & & $\begin{array}{l}0.0274^{* *} \\
(1.03)\end{array}$ & \\
\hline InMS & & $\begin{array}{l}0.0609^{* *} \\
(2.00)\end{array}$ & & $\begin{array}{l}0.0362^{* *} \\
(1.92)\end{array}$ \\
\hline $\ln E I * \ln I U$ & & & $\begin{array}{l}0.0320^{* *} \\
(2.30)\end{array}$ & \\
\hline $\ln E I * \operatorname{InMS}$ & & & & $\begin{array}{l}0.0405^{* *} \\
(2.15)\end{array}$ \\
\hline Observations & 60 & 60 & 70 & 70 \\
\hline Hansen ( $P$ Level) & 0.180 & 0.137 & 0.222 & 0.173 \\
\hline Sargan (P Level) & 0.393 & 0.317 & 0.403 & 0.315 \\
\hline $\begin{array}{l}\text { Arnello Bond } 1 \text { (P Level) } \\
\text { Arnello Bond } 2 \text { (P Level) }\end{array}$ & $\begin{array}{l}0.000 \\
0.228\end{array}$ & $\begin{array}{l}0.032 \\
0.109\end{array}$ & $\begin{array}{l}0.000 \\
0.202\end{array}$ & $\begin{array}{l}0.028 \\
0.102\end{array}$ \\
\hline $\begin{array}{l}\text { Number of Instruments } \\
\text { Number of Groups }\end{array}$ & $\begin{array}{l}9 \\
10\end{array}$ & $\begin{array}{l}9 \\
10\end{array}$ & $\begin{array}{l}9 \\
10\end{array}$ & $\begin{array}{l}9 \\
10\end{array}$ \\
\hline
\end{tabular}

Table 2 shows the results of System GMM regression analysis and diagnostic tests, including Arnello Bond test, Hansen and Sargan test. The regression analysis consists of four models where economic growth is the dependent variable and the first lag of economic growth, economic integration, human capital index, employment rate are taken as regressors. Internet Users and Mobile Phone Subscribers are taken as regressors with the perspective of ICT usage and readiness in model one and model two, respectively. Further, models three and four Internet Users and Mobile Phone Subscribers are used as regressors with economic integration interaction. 
Constant values represent intercept for the models that are $-0.363,-0.747,-0.518$ and -0.505 for model one, two, three and four, respectively. In all four models, first lag of economic growth impacts positively on economic growth. The coefficients are 0.800, 0.918, 0.821 and 0.951 for model one, two, three and four respectively. All coefficients are significant at $5 \%$ that confirms dynamic impact of economic growth in all four models. In model one constant is representing the intercept with a value of -.363. InEG_L1 represents first lag of economic growth with coefficient value of 0.800 that is significant at $5 \%$..This confirms the dynamic impact of economic integration in the model (Bong and Premaratne, 2018). Similarly, Economic Integration also positively impacts economic growth as coefficients are significant at a $5 \%$ significance level in all four models. $1 \%$ increase in economic integration will increase economic growth by $1.898 \%$ as the first coefficient for economic integration is 1.898 . The results are also consistent with previous studies (Kien, 2009; Sharma \& Chua 2000; Vogiatzoglou \& Nguyen, 2016 and Bong \& Premaratne, 2018). Further, the human capital index has a negative impact on economic growth (Malls, 2017). The coefficients were significant at $10 \%$ significance level. On the other hand, the employment rate has a positive but insignificant impact on economic growth (Ahmad \& Ahmed, 2016).

The results show the positive and significant impact of ICT on economic growth (Dimelis \& Papaioannou, 2010; Vu, 2011; Ahmed \& Ridzuan, 2013; Sassi \& Goaied, 2013) magnitude of mobile phone subscribers is greater than internet users. Model three and four show the moderating role of ICT for economic integration and growth nexus. The interaction term of internet users and economic integration in model three and mobile phone subscribers and economic integration in model four shows that increased internet users and mobile phone subscriptions strengthen economic integration and growth relationship. On the other hand, magnitude of mobile phone subscriptions is more significant than internet users. Table 2 also shows diagnostic tests for GMM regression, including Hansen and Sargan over-identification of restrictions and Arnello Bond Serial Correlation test. For all the four models, the instruments are not over identified as $p$ values for Sargan and Hansen tests are more than 0.05. Further, there is no serial correlation as $p$-value of $A R 2$ is more than 0.05 for all four models.

\section{Conclusion}

This study investigates the impact of economic integration on economic growth and explores the role of ICT for economic integration and growth relationship. Additionally, human capital and employment rate are taken as control variables for the study. The results revealed that economic integration and ICT both have significant and positive impact on economic growth. Furthermore, the impact of ICT readiness or mobile phone subscription on economic growth is more stronger as compared to ICT usage or internet users. Moreover, employment rate has a positive but insignificant impact on economic growth whereas the impact of human capital is negative on economic growth. Further, results also indicated that enhanced internet usage and mobile phone subscription will strengthen economic integration and growth nexus. More specifically, the role of mobile phone subscription is more proficient to enhance economic integration and growth relationship.

Conclusively, Economic integration could serve as an important factor for economic growth in ASEAN region. Public institutionPublic institutions should highly consider the implementation of economic integration with economic, social and political openness should 
highly consider the implementation of economic integration with economic, social and political openness to enhance growth in ASEAN countries. More specifically, our empirical results suggest that, the role of ICT usage and readiness is imperative to improve economic growth through economic integration.

The economic integration and growth nexus has an eminent place in economic research, yet the Impact of ICT is a relatively new phenomenon, studies upon it are limited. This study contributes to check the veracity of economic integration and ICT's impact on economic growth. Additionally, the role of ICT for economic integration and growth nexus via interaction term is absent in the literature at all. Hence, this research aims to bring forward the conceptualization of the role of ICT in context of ICT readiness and usage in ASEAN region. By empirical contribution, this study has contributed the existing body of knowledge by adding a study on impact of economic integration and ICT on economic growth and the role of ICT readiness and usage for economic integration and growth nexus in ASEAN region.

\section{Acknowledgement}

Financial support from Universiti Malaysia Sarawak (UNIMAS) - PGRG Postgraduate Student Research: 8847, is gratefully acknowledged.

\section{References}

Ahmad, J., \& Harnhirun, S. (1996). Cointegration and causality between exports and economic growth: evidence from the ASEAN countries. The Canadian Journal of Economics/Revue canadienne d'Economique, 29(2), 413-416.

Ahmed, E. M., \& Ridzuan, R. (2013). The impact of ICT on East Asian economic growth: panel estimation approach. Journal of the Knowledge Economy, 4(4), 540-555.

Ahmed, R. N., \& Ahmad, K. (2016). Impact of population on economic growth: A case study of Pakistan. Bulletin of Business and Economics, 5(3), 162-176.

Arellano, M., \& Bond, S. (1991). Some tests of specification for panel data: Monte Carlo evidence and an application to employment equations. The Review of Economic Studies, 58(2), 277-297.

Arellano, M., \& Bover, O. (1995). Another look at the instrumental variable estimation of error-components models. Journal of Econometrics, 68(1), 29-51.

ASEAN ICT Masterplan (2015). Retrieved From http://www.asean.org/index.php/resources/ publications/asean-publications/item/asean-ict-masterplan-2015.

ASEAN Secretariat (2014). Retrieved From www.aseanbriefing.com/news/2014/02/13/understanding-aseans-freetradeagreements.html.

ASEAN Secretariat (2017). Global Megatrends Implications for the ASEAN Economic Community. Retrieved From https://asean.org/global-megatrends/.

Baksa, D., \& Kónya, I. (2019). Convergence, productivity and debt: the case of Hungary (No. MT-DP-2019/16). IEHAS Discussion Papers.

Balassa, B. (1961). The Theory of Economic Integration. Homewood, Illinois: Richard D. Irwin.

Bhatt, P. R. (2014). Foreign direct investment in ASEAN countries, 1990-2012. Revista Galega de Economía, 23(4), 133-144.

Blundell, R., \& Bond, S. (1998). Initial conditions and moment restrictions in dynamic panel data models. Journal of Econometrics, 87(1), 115-143. 
Bong, A., \& Premaratne, G. (2018). Regional integration and economic growth in Southeast Asia. Global Business Review, 19(6), 1403-1415.

Cardona, M., Kretschmer, T., \& Strobel, T. (2013). ICT and productivity: conclusions from the empirical literature. Information Economics and Policy, 25(3), 109-125.

Danquah, M., Barimah, A., \& Ohemeng, W. (2013). Regional integration, trade and national efficiency in ECOWAS countries. The West African Economic Review, 2(1), 65-87.

Devereux, M. P., Griffith, R., \& Klemm, A. (2002). Can international tax competition explain corporate income tax reforms. mimeo.

Dewan, S., \& Kraemer, K. L. (2000). Information technology and productivity: evidence from country-level data. Management Science, 46(4), 548-562.

Dimelis, S. P., \& Papaioannou, S. K. (2010). FDI and ICT effects on productivity growth: A comparative analysis of developing and developed countries. The European Journal of Development Research, 22(1), 79-96.

Dowrick, S., \& Golley, J. (2004). Trade openness and growth: who benefits. Oxford Review of Economic Policy, 20(1), 38-56.

Dreher, A. (2006). Does globalization affect growth? Evidence from a new index of globalization. Applied Economics, 38(10), 1091-1110.

Ehigiamusoe, K. U., \& Lean, H. H. (2019). Do economic and financial integration stimulate economic growth? A critical survey. Economics: The Open-Access, Open-Assessment EJournal, 13(4), 1-27.

Fetahi-Vehapi, M., Sadiku, L., \& Petkovski, M. (2015). Empirical analysis of the effects of trade openness on economic growth: an evidence for South East European countries. Procedia Economics and Finance, 19(1), 17-26.

Grubert, H., \& Mutti, J. (2000). Do taxes influence where US corporations invest. National Tax Journal, 53(4), 825-839.

Hansen, L. P. (1982). Large sample properties of generalized method of moments estimatorsl. Econometrica, 50(4), 1029-1054.

Harrison, A. (1996). Openness and growth: A time-series, cross-country analysis for developing countries. Journal of Development Economics, 48(2), 419-447.

Haveman, J. D., Lei, V., \& Netz, J. S. (2001). International integration and growth: A survey and empirical investigation. Review of Development Economics, 5(2), 289-311.

Heshmati, A. (2016). Economic integration, currency union, and sustainable and inclusive growth in east Africa. Springer International Publishing.

Hew, D. (2008). Towards an ASEAN economic community by 2015. ISEAS Publishing: Singapore.

Hsiao, F. S., \& Hsiao, M. C. W. (2006). FDI, exports, and GDP in East and Southeast Asia-Panel data versus time-series causality analyses. Journal of Asian Economics, 17(6), 10821106.

Hussin, F., \& Saidin, N. (2012). Economic growth in ASEAN-4 Countries: A Panel data analysis. International Journal of Economics and Finance, 4(9), 119-129.

Inklaar, R., \& Timmer, M. P. (2015). The next generation of the penn world table. American Economic Review, 105(10), 3150-82.

Ishida, H. (2015). The effect of ICT development on economic growth and energy consumption in Japan. Telematics and Informatics, 32(1), 79-88.

Iyidoğan, P. V., Dalgiç, B., \& Akbulut, H. (2017). Is there a non-linear relationship between trade and growth? A panel threshold analysis for Central and Eastern European countries. Acta Oeconomica, 67(1), 117-136. 
Jorgenson, D. W., \& Vu, K. (2005). Information technology and the world economy. Scandinavian Journal of Economics, 107(4), 631-650.

Kahnert, F. P., Richards, E. S., \& Thomopoulos, P. (1969). Economic integration among developing countries. Paris: Development Center of the Organization for Economic Cooperation and Development (OECD).

Kamarudin, M. K. A., Wahab, N. A., Mohamad, M., Saudi, A. S. M., Samsurijan, M. S., Saad, M. H. M., \& Samsuri, N. N. S. (2018). Population Growth and Economic Development in Developing and Developed Countries. International Journal of Engineering \& Technology, 7(4), 123-127.

Khalid, A. M., \& Marasco, A. (2019). Do channels of financial integration matter for FDI's impact on growth? Empirical evidence using a panel. Applied Economics, 51(37), 40254045.

Kien, N. T. (2009). Gravity model by panel data approach: an empirical application with implications for the ASEAN free trade area. ASEAN Economic Bulletin, 26(3), 266-277.

Krugman, P. R. (1979). Increasing returns, monopolistic competition, and international trade. Journal of International Economics, 9(4), 469-479.

Kumar, N., \& Kumar, R. R. (2019). Relationship between ICT and international tourism demand: A study of major tourist destinations. Tourism Economics, 26(6), 908-925.

Kumar, R. R. (2012). Exploring the interactive effects of remittances, financial development and ICT in Sub-Saharan Africa: an ARDL bounds approach. African Journal of Economic and Sustainable Development, 1(3), 214-242.

Latif, Z., Latif, S., Ximei, L., Pathan, Z. H., Salam, S., \& Jianqiu, Z. (2018). The dynamics of ICT, foreign direct investment, globalization and economic growth: Panel estimation robust to heterogeneity and cross-sectional dependence. Telematics and Informatics, 35(2), 318-328.

Lipsey, R. G. (1960) The theory of customs unions: A general survey. The Economic Journal, 70(279), 496-513.

Loretz, S. (2007). Determinants of bilateral effective tax rates: Empirical evidence from OECD countries. Fiscal Studies, 28(2), 227-249.

Machlup, Frtiz. (1977). A history of thought on economic integration. New York: Columbia University Press.

Maiti, D., \& Awasthi, A. (2020). ICT Exposure and the Level of Wellbeing and Progress: A Cross Country Analysis. Social Indicators Research, 147(1), 311-343.

Makki, S. S., \& Somwaru, A. (2004). Impact of foreign direct investment and trade on economic growth: Evidence from developing countries. American Journal of Agricultural Economics, 86(3), 795-801.

Mall, S. (2017). Contribution of insurance on Economic growth in India: An Econometric approach (Presented at the 20th Annual Conference on Global Economic Analysis, West Lafayette, IN, USA). Purdue University, West Lafayette, IN: Global Trade Analysis Project (GTAP).

Masoud, N. (2014). Libya's IAS/IFRS adoption and accounting quality: what lessons from the European Union experience. International Journal of Accounting and Financial Reporting, 4(1), 118.

Mohanty, S. K., \& Pohit, S. (2007). Welfare gains from regional economic integration in Asia: $A S E A N+3$ or EAS. East Asian Bureau of Economic Research.

Moore, B., Akib, K., \& Sugden, S. (2018). E-commerce in Indonesia: A guide for Australian Business. Australian Trade and Investment Commission (Austrade). 
Murphy, R. H., \& O'Reilly, C. (2019). Applying panel vector autoregression to institutions, human capital, and output. Empirical Economics, 57(5), 1633-1652.

Nguyen, H. M., Bui, N. H., \& Vo, D. H. (2019). The Nexus between Economic Integration and Growth: Application to Vietnam. Annals of Financial Economics, 14(3), 1-16.

Ogbuabor, J. E., Anthony-Orji, O. I., Ogbonna, O. E., \& Orji, A. (2019). Regional integration and growth: New empirical evidence from WAEMU. Progress in Development Studies, 19(2), 123-143.

Öncel, A., \& Lubis, R. F. (2017). What impact has free trade area on economies of ASEAN-5 countries?. Theoretical and Applied Economics, 24(3), 51-62.

Paparas, D., Richter, C., \& Paparas, A. (2015). Fiscal policy and economic growth, empirical evidence in European Union. Turkish Economic Review, 2(4), 239-268.

Parvez, A. (2011). Development in library services with the advent of ICT based products \& services: A continuous process. International Journal of Digital Library Services, 1(2), 19.

Preepremmote, P., Santipolvut, S., \& Puttitanun, T. (2018). Economic integration in the ASEAN and its effect on empirical economic growth. Journal of Applied Economic Sciences, 4(58), 922-933

Putranti, I. R. (2016). EU Regulations on Illegal, Unreported, and Unregulated Fishing (IUU): Implications for ASEAN Community Fisheries Legal Frameworks. Russian Journal of Comparative Law, 19(3), 91-105.

Raheem, I. D., Tiwari, A. K., \& Balsalobre-Lorente, D. (2020). The role of ICT and financial development in $\mathrm{CO} 2$ emissions and economic growth. Environmental Science and Pollution Research, 27(2), 1912-1922.

Rassekh, F. (2007). Is international trade more beneficial to lower income economies? An empirical inquiry. Review of Development Economics, 11(1), 159-169.

Ridzuan, A. R., Mohammad, N. A. H., \& Ahmed, E. M. (2016). ASEAN4 prospective of exportled economic growth. Journal of Business Management and Economics, 7(1), 1-12.

Riyasat, A., \& Fatima, N. (2008). Impact of Information and Communication Technology LIS: major shifts and practices.6th International CALIBER University of Allahabad, Allahabad.

Roller, L. H., \& Waverman, L. (2001). Telecommunications infrastructure and economic development: A simultaneous approach. American Economic Review, 91(4), 909-923.

Seifallah, S., \& Mohamed, G. (2013). Financial development, ICT diffusion and economic growth: Lessons from MENA region. Financial development, ICT diffusion and economic growth. Telecommunications Policy, 37(1), 252-261.

Sharma, S. C., \& Chua, S. Y. (2000). ASEAN: economic integration and intra-regional trade. Applied Economics Letters, 7(3), 165-169.

Shuaibu, M. (2015). Trade liberalization and intra-regional trade: a case of selected ECOWAS countries. African Development Review, 27(1), 27-40.

Steiner, N. D., \& Martin, C. W. (2012). Economic integration, party polarisation and electoral turnout. West European Politics, 35(2), 238-265.

Sukirno, S. (2012). Ekonomi Makro Teori Pengantar. Jakarta: Rajawali Pers.

Tan, B. W., \& Tang, C. F. (2016). Examining the causal linkages among domestic investment, FDI, trade, interest rate and economic growth in ASEAN-5 countries. International Journal of Economics and Financial Issues, 6(1), 214-220.

Viner, J. (1950). The Customs Union Issue. Oxford University Press. 
Vogiatzoglou, K., \& Nguyen, P. N. T. (2016). Economic openness and economic growth: A cointegration analysis for ASEAN-5 countries. The European Journal of Applied Economics, 13(2), 10-20.

$\mathrm{Vu}, \mathrm{K}$. M. (2011). ICT as a source of economic growth in the information age: Empirical evidence from the 1996-2005 period. Telecommunications Policy, 35(4), 357-372.

Vu, Y. H., Nguyen, N. T., Nguyen, T. T., \& Pham, A. T. (2019, January). The threshold effect of government's external debt on economic growth in emerging countries. In International Econometric Conference of Vietnam (pp. 440-451). Springer, Cham.

Ward, M. R., \& Zheng, S. (2016). Mobile telecommunications service and economic growth: Evidence from China. Telecommunications Policy, 40(3), 89-101.

World Development Indicator (2019). World Bank. Retreived from http://databank.worldbank.org/data/download/WDI_excel.zip2019.

Yanikkaya, H. (2003). Trade openness and economic growth: a cross-country empirical investigation. Journal of Development Economics, 72(1), 57-89.

Yousefi, A. (2011). The impact of information and communication technology on economic growth: evidence from developed and developing countries. Economics of Innovation and New Technology, 20(6), 581-596.

Yusuf, M. O. (2005). Integrating information and communication technologies (ICTs) in Nigerian tertiary education. African Educational Research Journal, 2(5), 43-50.

Zuhdi, U., Mori, S., \& Kamegai, K. (2012). Analyzing the role of ICT sector to the national economic structural changes by decomposition analysis: The case of Indonesia and Japan. Procedia-Social and Behavioral Sciences, 65(2), 749-754. 